\title{
Potential of Local Bio-Geoengineering to Mitigate Dangerous Temperature Increases in a Global Warming Scenario
}

\author{
Salvador Nogués and Joaquim Azcón-Bieto*
}

Departament de Biologia Vegetal, Universitat de Barcelona, Barcelona, Spain

\begin{abstract}
Crops and forests are already responding to rising atmospheric carbon dioxide and air temperatures. Increasing atmospheric $\mathrm{CO}_{2}$ concentrations are expected to enhance plant photosynthesis. Nevertheless, after long-term exposure, plants acclimate and show a reduction in photosynthetic activity (i.e. down-regulation). If in the future the Earth's temperature is allowed to rise further, plant ecosystems and food security will both face significant threats. The scientific community has recognized that an increase in global temperatures should remain below $2^{\circ} \mathrm{C}$ in order to combat climate change. All this evidence suggests that, in parallel with reductions in $\mathrm{CO}_{2}$ emissions, a more direct approach to mitigate global warming should be considered. We propose here that global warming could be partially mitigated directly through local bio-geoengineering approaches. For example, this could be done through the management of solar radiation at surface level, i.e. by increasing global albedo. Such an effect has been documented in the south-eastern part of Spain, where a significant surface air temperature trend of $-0.3^{\circ} \mathrm{C}$ per decade has been observed due to a dramatic expansion of greenhouse horticulture.
\end{abstract}

Keywords: Global warming; Plant ecosystems; Local biogeoengineering; Albedo

The rapid increase in the concentration of atmospheric $\mathrm{CO}_{2}$ due to continued anthropogenic emissions of this gas is the main factor driving global climate change [1]. Global temperature increases by 2100 are likely to range from $1.1^{\circ} \mathrm{C}$ to $6.4^{\circ} \mathrm{C}$, depending on the climate sensitivity of the Earth and the climate model used [1]. In order to limit global warming to $2^{\circ} \mathrm{C}$ or less [2,3], a target which was proposed by the European Union [4], some authors predict that a reduction in emissions of up to $90 \%$ by 2050 would be required [5]. However, efforts to reduce carbon emissions so far have been relatively ineffective [6].

Both $\mathrm{CO}_{2}$ and temperature have enormous effects on the physiology of plants and other photosynthetic organisms. While carbon dioxide is the substrate of photosynthesis and is also the by-product of respiratory processes, temperature has a very strong effect on both of these biochemical reactions. Therefore, climate change will certainly have a significant impact on plant performance in the future. Indeed, the effects of elevated levels of $\mathrm{CO}_{2}$ on photosynthesis and respiration rates could improve the carbon balance in plants: light-saturated carbon uptake, diurnal carbon assimilation, and plant growth and production would rise, while costs associated with leaf stomatal conductance, tissue nitrogen content and respiration would decrease [7-12].

Also, plants can act as a sink or source for atmospheric $\mathrm{CO}_{2}$ [8]. Since the net exchange of carbon dioxide lies in the balance between respiration and photosynthetic processes, small changes in either process can have a significant impact on the net exchange. An increase in $\mathrm{CO}_{2}$ concentration from 300-350 to $680 \mathrm{mmol} \mathrm{mol}^{-1}$ has been described as enhancing plant growth by $7 \%$ to $25 \%[13,14]$. According to the literature [15], this increase in growth is caused by stimulation in photosynthetic rates of between $35 \%$ and $60 \%$. Although the initial stimulation of net photosynthesis associated with elevated $\mathrm{CO}_{2}$ concentrations is sometimes maintained during long-term exposure [16], it is often partially reversed in an acclimation process, often referred to as 'down-regulation' [7,15]. Decreased Rubisco carboxylation occurs through two basic mechanisms: one that involves $\mathrm{C}$ source/sink relationships and a second that involves $\mathrm{N}$ allocation [9].

On the other hand, several papers $[17,18]$ raise alarms about the possible negative and irreversible effects on plant and crop performance as a result of the range of temperature increases that have been forecast by the IPCC [1] for the end of the century. For example, in 2003, Europe experienced an extreme climate anomaly, with July temperatures up to $6^{\circ} \mathrm{C}$ above the long-term average, and annual precipitation deficits of up to $300 \mathrm{~mm} \mathrm{yr}^{-1}$. This caused a $30 \%$ reduction in gross primary productivity, which in turn resulted in a highly anomalous net source of $\mathrm{CO}_{2}\left(0.5 \mathrm{Pg} \mathrm{C} \mathrm{yr}^{-1}\right)$ [17]. An increase in temperatures of $4^{\circ} \mathrm{C}$ decreased the net ecosystem $\mathrm{CO}_{2}$ exchange in grasses over a two year period by inducing drought that suppressed net primary productivity in the extreme year and by stimulating heterotrophic respiration of the soil biota in the subsequent year [18]. This study also concluded that at least two years are required for the net ecosystem $\mathrm{CO}_{2}$ exchange to recover after a temperature stress.

Therefore, there is a considerable risk that plant production (i.e. food and feed supply) could be very negatively affected by excessive temperature increases in the future [19] if $\mathrm{CO}_{2}$ emissions are not sufficiently reduced through efforts at an international level. Even if these emissions were to come to a complete standstill, the effects on climate would be long lasting. Furthermore, it has been suggested that climate change is largely irreversible for many years after emissions come to a stop [20].

In addition to proposals for the capture of $\mathrm{CO}_{2}$ from the air, and for capture and storage of $\mathrm{CO}_{2}$ from point sources (i.e. the $\mathrm{CO}_{2}$ would then be compressed and transported for storage in geological formations, in the ocean, in mineral carbonates, or for use in industrial processes), a variety of geoengineering technological solutions have been put forward in order to directly mitigate climate change [21]. Most of

*Corresponding author: Joaquim Azcón-Bieto, Departament de Biologia Vegetal Universitat de Barcelona, Barcelona, Spain, E-mail: jazcon@ub.edu

Received April 10, 2013; Accepted June 28, 2013; Published July 03, 2013

Citation: Nogués S, Azcón-Bieto J (2013) Potential of Local Bio-Geoengineering to Mitigate Dangerous Temperature Increases in a Global Warming Scenario. J Earth Sci Clim Change 4: 143. doi:10.4172/2157-7617.1000143

Copyright: ( 2013 Nogués S, et al. This is an open-access article distributed under the terms of the Creative Commons Attribution License, which permits unrestricted use, distribution, and reproduction in any medium, provided the original author and source are credited. 
these geoengineering solutions would typically require the creation of completely new and expensive infrastructures and industries on a vast scale. Furthermore, their continued maintenance into the indefinite future would certainly by also expensive, particularly in the case of stratospheric sulphate aerosols and iron fertilization where continual re-application year after year would be necessary [22,23]. Also, it is expected that all of these solutions would alter regional climates and would have substantial effects on climate variables other than temperature, such as precipitation. These geoengineering solutions could reduce overall precipitation, particularly that of the Asian and African summer monsoon, thereby threatening the food supply of billions [24]. Consequently, concerns about the risks posed by geoengineering to food security have been raised. Clearly, other solutions exist which, while contributing to a lesser extent to the mitigation of climate change on a global scale, may prove to be less risky and more practical in the short term as discussed below.

So, is it possible to avoid the effects of global warming if $\mathrm{CO}_{2}$ emissions continue as they are? This is an important question since most of the negative effects of climate change, not only those affecting plants and ecosystems, are related to an increase in global temperatures. We propose here that the extent of global warming can be controlled directly through local geo-engineering approaches, which could be achieved at a reasonable cost. An example of this relatively low cost approach is connected with the management of solar radiation (i.e. by increasing the global albedo). Evidence for this can be found in the south-eastern part of Spain where a significant surface air temperature trend of $-0.3^{\circ} \mathrm{C}$ per decade has been observed due to a dramatic expansion of greenhouse horticulture (reaching a continuous area of 26,000 ha in 2007), the most extensive greenhouse area in the world Figure 1 [25]. Increasing urban albedo can reduce air temperatures and can result in less absorption of incoming solar radiation by the surface-troposphere system [26]. Since pavements and roofs typically constitute over $60 \%$ of urban surfaces, the albedo of both could be increased through the use of reflective materials by $c a .0 .25 \mathrm{~W} \mathrm{~m}^{-2}$ and $0.15 \mathrm{~W} \mathrm{~m}^{-2}$, respectively. This would result in a net albedo increase for urban areas of $c a .0 .1 \mathrm{~W}$ $\mathrm{m}^{-2}$, thereby offsetting around $44 \mathrm{Gt}$ of $\mathrm{CO}_{2}$ emissions [26]. This $44 \mathrm{Gt}$ $\mathrm{CO}_{2}$ offset is over 1 year of the 2025 projected world-wide emission of 37 Gt of $\mathrm{CO}_{2}$ per year [26].

Moreover, Ridgwell et al. [27] have proposed a new approach in the mitigation of surface warming, where crop varieties which have specific leaf glossiness and/or canopy morphological traits could be chosen specifically in order to maximize solar reflectivity [27]. Using an ocean-atmosphere-vegetation model, Singarayer et al. [21] have investigated to what extent the regional effectiveness of crop albedo bio-geoengineering might have on a progressively warming climate [7]. They found that the averted warming due to increasing the albedo of the crop canopy by 0.04 is regionally and seasonally specific, with the greatest cooling of $c a .1^{\circ} \mathrm{C}$ for Europe in summer whereas in the low latitude monsoonal SE Asian regions of high density cropland, the greatest cooling is experienced in winter. However, despite the small global impact, regionally focused schemes such as crop albedo bio-geoengineering have provided certain benefits. Furthermore, according to models, solar-radiation geoengineering in high- $\mathrm{CO}_{2}$ environments generally produces an increase in crop yields, largely because temperature stresses are diminished while the benefits of $\mathrm{CO}_{2}$ fertilization are retained [28]. However, Irvine et al. [6] have looked at the regional and global impacts of different bio-geoengineering approaches and have found that the cooling effect of surface albedo modification is seasonal and mostly confined to the areas of application. In terms of urban and cropland geoengineering, the global effects are

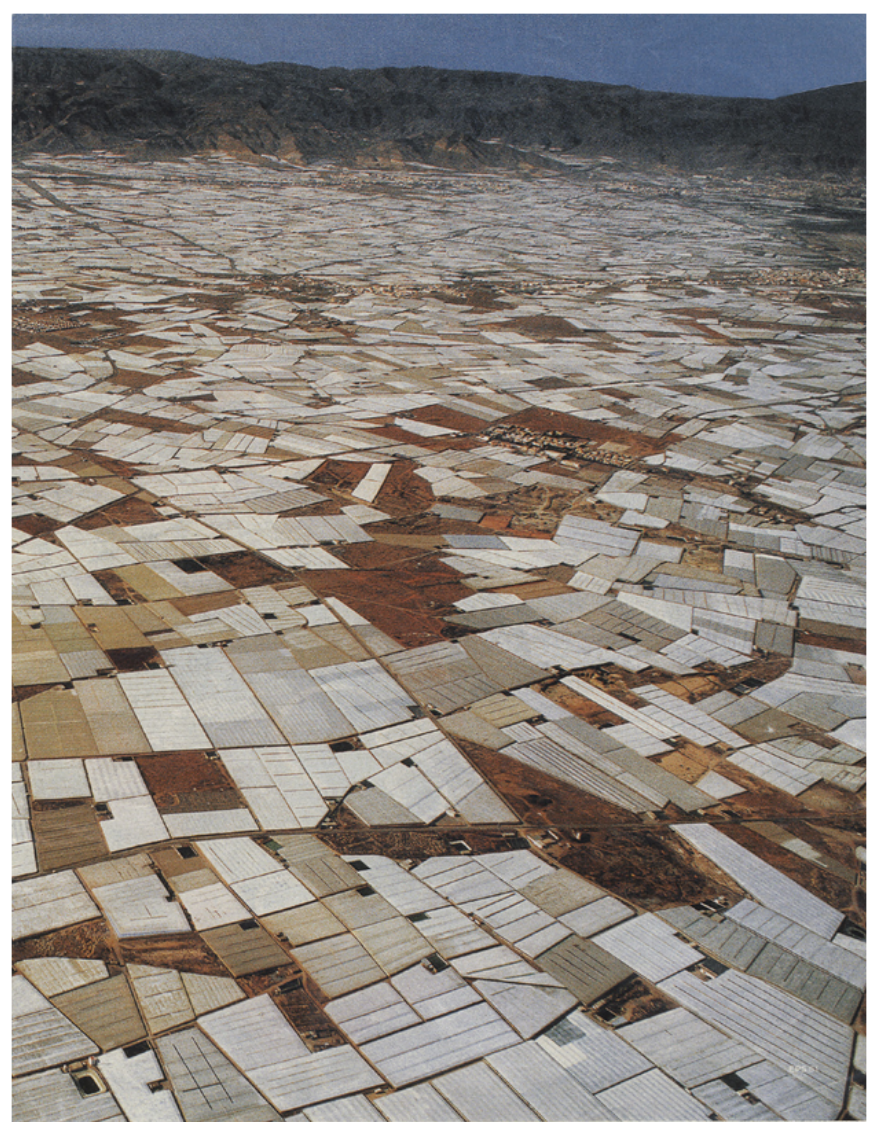

Figure 1: The 'plastic sea' of El Ejido, Almeria, Spain, the most extensive greenhouse area in the world (Photo: Ramón Vallejo, Universitat de Barcelona).

minor, but since they are located within areas of human activity, they may provide some regional benefits.

In summary, the selection of crop varieties with higher reflectivity, the use of reflective pavements, painting buildings and roofs with light colours, and other similar bio-geoengineering approaches at a local level will lead to an increase in albedo and thus decrease global temperatures. In addition to efforts currently underway to reduce $\mathrm{CO}_{2}$ emissions, this body of evidence suggests that the use of local biogeoengineering can increase local surface albedo and, consequently, decreasing surface temperature, that in turn could increase growth rates of plants.

However, it must be stated that we are not advocating the use of local bio-geoengineering as an alternative to reducing $\mathrm{CO}_{2}$, but rather that these bio-geoengineering solutions could be implemented in parallel with other programs for the reduction of $\mathrm{CO}_{2}$ emissions. Furthermore, these could easily be implemented in developing countries, and at the same time help to bring new opportunities to their economies. Each country should therefore find the local 'non-costly' bio-geoengineering approaches that best suit their situation and adapted to their capabilities (such as changing crop albedo, urban surfaces, and so on).

\section{Acknowledgements}

This study was supported in part by the Spanish Ministry of Science and Technology PALEOISOCROP project (CGL2009-13079-C02). This project studies cultivated plants and forest trees responses to past global changes that provide valuable insights for predicting future responses to a changing environment of plants grown in Mediterranean conditions. 
Citation: Nogués S, Azcón-Bieto J (2013) Potential of Local Bio-Geoengineering to Mitigate Dangerous Temperature Increases in a Global Warming Scenario. J Earth Sci Clim Change 4: 143. doi:10.4172/2157-7617.1000143

\section{References}

1. IPCC (2007) Climate Change 2007: Working Group I: The Physical Science Basis.

2. Meinshausen M, Meinshausen N, Hare W, Raper SC, Frieler K, et al. (2009) Greenhouse-gas emission targets for limiting global warming to 2 degrees $\mathrm{C}$. Nature 458: 1158-1162.

3. Peters GP, Andrew RM, Boden T, Canadell JG, Ciais P, et al. (2012) The challenge to keep global warming below $2{ }^{\circ} \mathrm{C}$. Nature Climate Change 3: 4-6.

4. Commission of European Communities (2007) Limiting Global Climate Change to $2^{\circ}$ Celsius The way ahead for 2020 and beyond. Energy for a changing world.

5. Weaver AJ, Zickfeld K, Montenegro A, Eby M (2007) Long term climate implications of 2050 emission reduction targets. Geophys Res Lett 34

6. Irvine PJ, Ridgwell A, Lunt DJ (2011) Climatic effects of surface albedo geoengineering. J Geophys Res-Atmos 116.

7. Ainsworth EA, Long SP (2005) What have we learned from 15 years of freeair $\mathrm{CO} 2$ enrichment (FACE)? A meta-analytic review of the responses of photosynthesis, canopy properties and plant production to rising $\mathrm{CO} 2$. New Phytol 165: 351-371.

8. Aranjuelo I, Pardo A, Biel C, Save R, Azcón-Bieto J, et al. (2009) Leaf carbon management in slow-growing plants exposed to elevated $\mathrm{CO}$. Glob Change Biol 15: 97-109.

9. Aranjuelo I, Ebbets AL, Evans RD, Tissue DT, Nogués S, et al. (2011) Maintenance of $C$ sinks sustains enhanced $C$ assimilation during long-term exposure to elevated [CO2] in Mojave Desert shrubs. Oecologia 167: 339-354.

10. Gomez-Casanovas N, Blanc-Betes E, Gonzalez-Meler MA, Azcón-Bieto J (2007) Changes in respiratory mitochondrial machinery and cytochrome and alternative pathway activities in response to energy demand underlie the acclimation of respiration to elevated $\mathrm{CO} 2$ in the invasive Opuntia ficus-indica. Plant Physiol 145: 49-61.

11. Pardo A, Aranjuelo I, Biel C, Savé R, Azcón-Bieto J, et al. (2009) Effects of long-term exposure to elevated $\mathrm{CO}(2)$ conditions in slow-growing plants using a (12)C-enriched CO(2)-labelling technique. Rapid Commun Mass Spectrom 23: $282-290$

12. Sage RF, Way DA, Kubien DS (2008) Rubisco, Rubisco activase, and global climate change. J Exp Bot 59: 1581-1595.

13. Hadley P, Batts GR, Ellis RH, Morison JIL, Pearson S, et al. (1995) Temperature gradient chambers for research on global environment change. II. A twin-wall tunnel system for low-stature, field-grown crops using a split heat pump. Plant Cell Environ 18: 1055-1063.
14. Daepp M, Suter D, Almeida JPF, Isopp H, Hartwig UA et al. (2000) Yield response of Lolium perenne swards to free air $\mathrm{CO} 2$ enrichment increased ove six years in a high $\mathrm{N}$ input system on fertile soil. Glob Change Biol 6: 805-816.

15. Long SP, Ainsworth EA, Rogers A, Ort DR (2004) Rising atmospheric carbon dioxide: plants FACE the future. Annu Rev Plant Biol 55: 591-628.

16. Davey PA, Olcer H, Zakhleniuk O, Bernacchi CJ, Calfapietra C, et al. (2006) Can fast-growing plantation trees escape biochemical down-regulation of photosynthesis when grown throughout their complete production cycle in the open air under elevated carbon dioxide? Plant Cell Environ 29: 1235-1244.

17. Ciais P, Reichstein M, Viovy N, Granier A, Ogée J, et al. (2005) Europe-wide reduction in primary productivity caused by the heat and drought in 2003 Nature 22: 529-533

18. Arnone III JA, Verburg PSJ, Johnson DW, Larsen JD, Jasoni RL (2008) Prolonged suppression of ecosystem carbon dioxide uptake after an anomalously warm year. Nature 455: 383-386.

19. Battisti DS, Naylor RL (2009) Historical Warnings of Future Food Insecurity with Unprecedented Seasonal Heat. Science 323: 240-244.

20. Solomon S, Plattner GK, Knutti R, Friedlingstein P (2009) Irreversible climate change due to carbon dioxide emissions. Proc Natl Acad Sci USA 106: 1704 1709.

21. Singarayer JS, Ridgwell A, Irvine P (2009) Assessing the benefits of crop albedo bio-geoengineering. Environ Res Lett 4.

22. Wigley TML (2006) A Combined Mitigation/Geoengineering Approach to Climate Stabilization. Science 314: 452-454

23. Zeebe RE, Archer D (2005) Feasibility of ocean fertilization and its impact on future atmospheric CO2 levels. Geophys Res Lett 32.

24. Robock A (2008) Whither Geoengineering? Science 320: 1166-1167.

25. Campra P, Garcia M, Canton Y, Palacios-Orueta A (2008) Surface temperature cooling trends and negative radiative forcing due to land use change toward greenhouse farming in southeastern Spain. J Geophys Res-Atmos 113.

26. Akbari H, Menon S, Rosenfeld A (2009) Global cooling: increasing world-wide urban albedos to offset CO2. Climatic Change 94: 275-286.

27. Ridgwell A, Singarayer JS, Hetherington AM, Valdes PJ (2009) Tackling Regional Climate Change By Leaf Albedo Bio-geoengineering. Curr Biol 19 146-150.

28. Pongratz J, Lobell DB, Cao L, Caldeira K (2012) Crop yields in a geoengineered climate. Nature Climate Change 2: 101-105.
Citation: Nogués S, Azcón-Bieto J (2013) Potential of Local Bio-Geoengineering to Mitigate Dangerous Temperature Increases in a Global Warming Scenario. J Earth Sci Clim Change 4: 143. doi:10.4172/2157-7617.1000143
Submit your next manuscript and get advantages of OMICS Group submissions

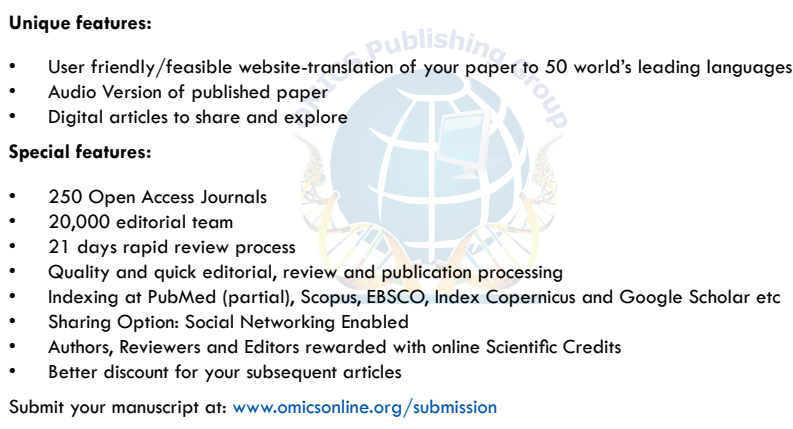

